\title{
Taxonomic resolution of the Triassic-Jurassic sporomorph record in East Greenland
}

\author{
LUKE MANDER \\ School of Biology and Environmental Sciences, University College Dublin, Belfield, Dublin 4, Ireland \\ Current address: Department of Plant Biology, University of Illinois at Urbana-Champaign, 505 S. Goodwin Avenue, Urbana, IL 61801, USA \\ (e-mail: luke.mander@gmail.com)
}

\begin{abstract}
Sporomorphs (pollen and spores) provide valuable information about vegetation history over a range of temporal and spatial scales. However, sporomorphs can be morphologically invariant among species within genera, and among genera within certain families. In some cases, the parent plant of a sporomorph is unknown. These factors blur the relationship between sporomorph assemblages and the source vegetation, and reduce the taxonomic precision of vegetation reconstructions based on sporomorphs. This study investigates the taxonomic precision with which sporomorphs record vegetation across the Triassic-Jurassic transition ( $\mathrm{Tr}-\mathrm{J}$ ) at Astartekløft, East Greenland. Results indicate that reconstructions of $\mathrm{Tr}-\mathrm{J}$ vegetation at Astartekløft based on sporomorphs are hampered by considerable taxonomic imprecision. Something is known of the botanical affinity of almost all sporomorphs at Astartekløft at the class level, but just $50 \%$ of sporomorph taxa have a known botanical affinity at the family level. Additionally, $\sim 23 \%$ of all sporomorph taxa at Astartekløft have affinities to more than one parent plant class, and $\sim 36 \%$ of sporomorph taxa have affinities to more than one parent plant family. This taxonomic imprecision should be accounted for when interpreting percentage diagrams of sporomorph taxa across the Tr-J. J. Micropalaeontol. 30(2): 107-118, September 2011.
\end{abstract}

KEYWORDS: palynology, taphonomy, Triassic, Jurassic, extinction

\section{INTRODUCTION}

Following the seminal work of von Post (1916) the use of dispersed sporomorphs (pollen and spores) to reconstruct vegetation history is now commonplace. Sporomorphs have provided valuable information on vegetation from the Palaeozoic to the present day, and on spatial scales ranging from moss polsters (e.g. Domínguez-Vázquez et al., 2004) to continents and biomes (e.g. Overpeck et al., 1992; Mitchell, 2011). In some plant groups, such as liverworts (e.g. Schuster, 1992) and hornworts (e.g. Villarreal et al., 2007), sporomorph morphology is an important character used to distinguish between different species. However, in other plant groups sporomorphs can be morphologically invariant among species within genera, such as the pollen of Quercus (oaks) (e.g. Liu et al., 2007), and possibly morphologically invariant among many genera within certain families, such as the Poaceae (grasses) (e.g. Wodehouse, 1935). Thus, sporomorph identification can suffer from limited taxonomic resolution (e.g. Birks \& Birks, 2000; Jackson \& Booth, 2007). In some cases the parent plant of a dispersed sporomorph is unknown. This is often the case in studies of extinct plant groups in pre-Quaternary time, where the unequivocal linkage of dispersed sporomorphs to parent plants is reliant on the discovery of sporomorphs in situ in fossilized reproductive structures (e.g. Balme, 1995). Where a sporomorph has not been found in situ, its botanical affinity may be interpreted by morphological and/or ultrastructural comparison with other sporomorphs (e.g. Batten \& Dutta, 1997).

Morphological invariance among sporomorphs, and the absence of reliable occurrences of dispersed sporomorph taxa in situ in fossilized reproductive structures or fertile foliage, together impart a degree of taxonomic imprecision to a vegetation reconstruction based on sporomorphs. This controls the taxonomic resolution of a sporomorph assemblage, which is the taxonomic level at which the source vegetation can be reconstructed from dispersed sporomorphs. The taxonomic resolution of a sporomorph assemblage lies somewhere on a conceptual sliding scale. At one end of the scale, the identity of the parent plant of each and every sporomorph in an assemblage is known at the species level: everything is known of the botanical affinities of the sporomorphs and the taxonomic resolution of the assemblage is highest. At the opposite end of the scale, the identity of the parent plant of each and every sporomorph in an assemblage is completely unknown: nothing is known of the botanical affinities of the sporomorphs and the taxonomic resolution of the assemblage is lowest. Assemblages of dispersed sporomorphs lie somewhere between these two extremes, and contain a mixture of sporomorphs that are morphologically invariant at species, genus or family level, together with some sporomorphs whose affinities at low taxonomic levels, such as family or genus, are unknown.

Taxonomic imprecision blurs the relationship between a sporomorph assemblage and the source vegetation. This hampers efforts to understand plant life during episodes of major environmental and biotic change, such as the Triassic-Jurassic mass extinction ( $\mathrm{Tr}-\mathrm{J} ; \sim 200 \mathrm{Ma}$ (Schoene et al., 2010)). The $\mathrm{Tr}-\mathrm{J}$ is one of the 'Big Five' mass extinction events of the Phanerozoic and resulted in the extinction of $23 \%$ of marine families and $22 \%$ of terrestrial families (Benton, 1995). However, the only confirmed global plant family extinction during this period of major global change, that of the Peltaspermaceae (a clade of seedferns; see McElwain \& Punyasena, 2007), is masked in the sporomorph record because the pollen produced by this family (Cycadopites; Townrow, 1960) was also produced by at least four orders of plants (Cycadales, Ginkgoales, Bennettitales and Peltaspermales; Mander et al., 2010). Additionally, detailed investigations of plant macrofossils (mostly leaves) at a $\operatorname{Tr}-\mathrm{J}$ boundary section at Astartekløft in East Greenland have revealed that four cycad leaf genera (Doratophyllum, Ctenis, Pseudoctenis and Nilssonia) are present in Triassic sediments, but are absent from Jurassic rocks owing to their local extinction 


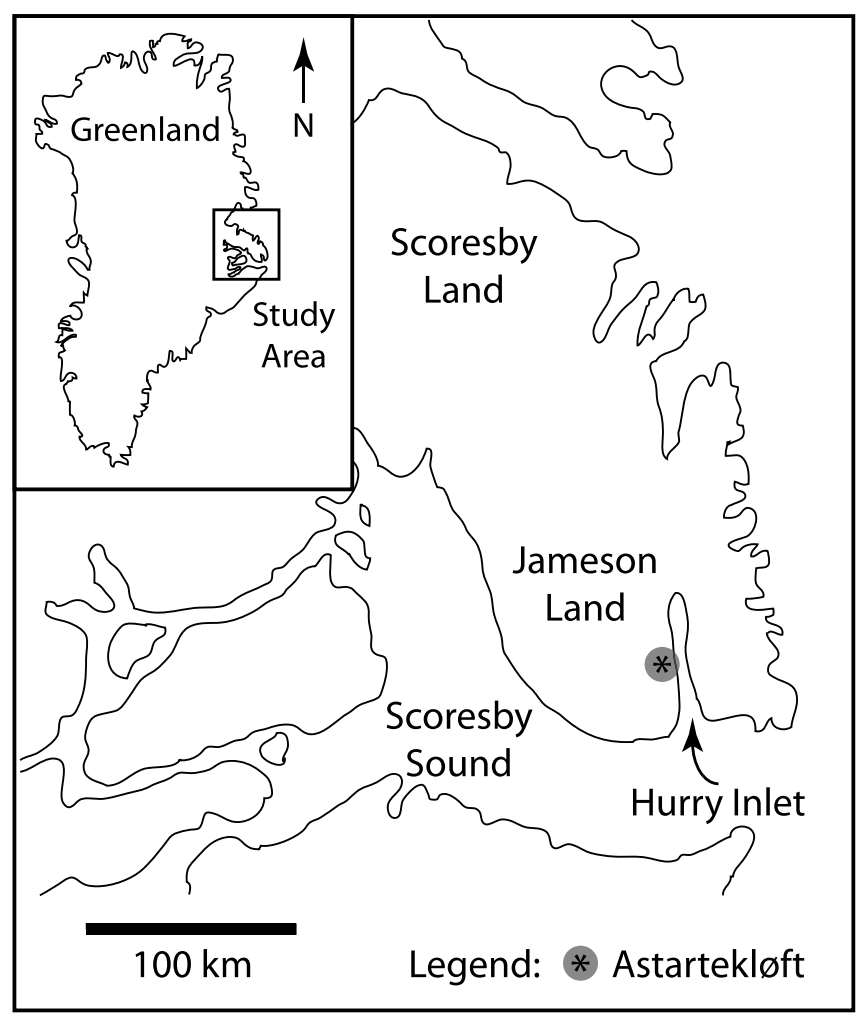

Fig. 1. Map showing the location of the Astartekløft section in Jameson Land, East Greenland (after McElwain et al., 2007).

or emigration (McElwain et al., 2007). This vegetation change is not recorded by sporomorphs at the same locality, partly because of morphological invariance among the 'boat-shaped' monosulcate pollen grains that were produced by most Mesozoic cycads (Balme, 1995; Mander et al., 2010).

This study aims to investigate the taxonomic precision with which sporomorphs record the source vegetation across the $\mathrm{Tr}-\mathrm{J}$ at Astartekløft by measuring: (1) the proportion of sporomorphs that have a known botanical affinity at Astartekløft; (2) the proportion of sporomorphs that have affinities to more than one parent plant at Astartekløft.

\section{MATERIALS AND METHODS}

\section{Geological setting and stratigraphy}

The material for this study was derived from rocks that crop out at Astartekløft in Jameson Land, East Greenland (Fig. 1). The rock succession at this locality comprises the fluvial-lacustrine Kap Stewart Group, which was deposited on the margins of the perennial hydrologically closed Kap Stewart Lake, situated in the south of the East Greenland rift basin (Dam \& Surlyk, 1992). This locality has yielded exceptionally well-preserved plant macrofossils (e.g. Harris, 1937; McElwain et al., 2007) that are restricted to a series of muddy and silty fossiliferous layers, hereafter referred to as 'plant beds' (Fig. 2). These plant beds are located in the sandy and shaley Primulaelv Formation, which was deposited in a delta plain setting (Dam \& Surlyk, 1992, 1993; Surlyk, 2003; McElwain et al., 2007). The absence of marine palynomorphs from the Kap Stewart Group at Astartekløft indicates that environments of deposition were

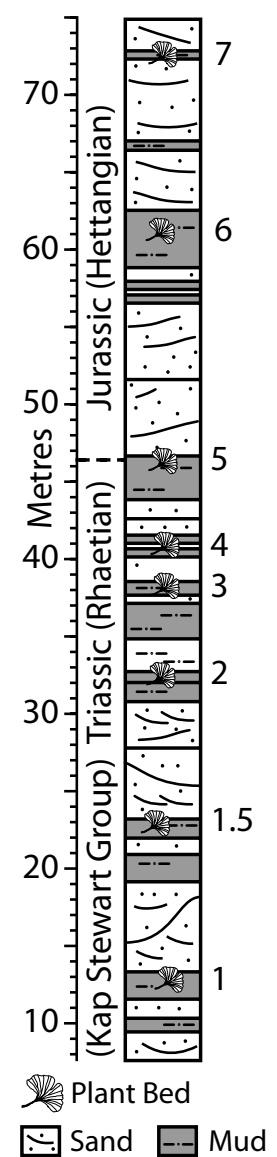

Fig. 2. Schematic sedimentary log of the Astartekløft section (adapted from Hesselbo et al., 2002; McElwain et al., 2007, and also shown in Belcher et al., 2010 and Mander et al., 2010). Plant beds numbered 1-7 and highlighted by schematic Ginkgo leaves. Plant beds 1-5 represent deposition by floodwaters into overbank environments, plant bed 6 represents a poorly developed coal swamp and plant bed 7 represents a shallow pool developed in a semi-abandoned abandoned channel (McElwain et al., 2007). Position of Triassic/Jurassic boundary approximated by first appearance of the pollen grain Cerebropollenties thiergartii, following Kuerschner et al. (2007) and Bonis et al. (2009) (see Mander et al., 2010).

exclusively terrestrial (Pedersen \& Lund, 1980; Koppelhus, 1996; Mander et al., 2010).

\section{Collection of samples and palynological techniques}

Rock samples were collected at $10 \mathrm{~cm}$ intervals from within each plant bed at Astartekløft (Fig. 2). Samples from plant bed 6 consist of coaly mudstone, and samples from all other plant beds consist of dark grey mudstones and siltstones. Between $15 \mathrm{~g}$ and $20 \mathrm{~g}$ of each sample was washed and crushed and dried for 24 hours at $60^{\circ} \mathrm{C}$. Each sample was treated twice alternately with cold $\mathrm{HCl}(30 \%)$ to remove carbonate minerals and with cold HF $(38 \%)$ to remove silicate minerals. The residue from each sample was washed with water until $\mathrm{pH}$ neutral, then sieved with $250 \mu \mathrm{m}$ and $15 \mu \mathrm{m}$ polypropylene mesh. Finally, organic and inorganic residues were separated using $\mathrm{ZnCl}_{2}$. No oxidation techniques were used during the preparation of sporomorphs. Two slide preparations were made in glycerine jelly and these are available upon request. 
A total of 40 rock samples were productive for sporomorphs from plant beds 1-7. A count of between 350 and 400 sporomorphs was made but where one morphotype dominated the sporomorph assemblage, counts were increased until at least 150 sporomorphs of the non-dominant types were recorded. Slides were counted in complete transects and included the centre and edges of the slides. A total of 14579 sporomorphs were recorded from the 40 productive samples. Sporomorph identification was based on Morbey (1975), Lund (1977) and Pedersen \& Lund (1980). A full data matrix showing occurrences of sporomorphs within samples from each plant bed at Astartekløft is available in Mander et al. (2010).

\section{Measuring the taxonomic resolution of the $\mathbf{T r}-\mathbf{J}$ sporomorph record at Astartekløft}

In order to measure the taxonomic resolution of the sporomorph record at Astartekløft, it was necessary to interpret the botanical affinities of each sporomorph taxon. Accordingly, the published literature was searched for sporomorphs found in situ in reproductive structures of fossil plant taxa. Most in situ occurrences are recorded in the annotated catalogue of fossil in situ spores and pollen grains of Balme (1995), but additional references have been consulted where this catalogue was found to be deficient or outdated. The botanical affinities of spores recovered from Astartekløft are shown in Table 1 and the botanical affinities of pollen grains recovered from Astartekløft are shown in Table 2. The parent plants of sporomorphs recovered from Astartekløft have been placed into a classification scheme comprising family, order and class. Where possible, each classification is supported by a published reference. In cases where no published information on the botanical affinity of a particular sporomorph was available, the sporomorph in question has either been classified to a parent plant class by analogy with other representatives of that class, or has been left unassigned to a parent plant.

The proportion of sporomorphs that have a known botanical affinity within each sample was calculated by dividing the total number of sporomorph taxa that have a known botanical affinity in a given sample by the total number of sporomorph taxa in that sample. Samples containing a higher proportion of sporomorphs with a known botanical affinity offer a more taxonomically precise picture of the source vegetation than samples having a lower proportion of sporomorphs with a known botanical affinity.

Certain sporomorphs are morphologically invariant among certain parent plant taxa and thus have affinities to more than one parent plant (Tables 1,2). The abundance of these multiaffinity sporomorphs has been reported as a proportion of those sporomorphs that have a known botanical affinity. This proportion was calculated by dividing the total number of sporomorph taxa with affinities to more than one parent plant in a given sample by the total number of sporomorph taxa that have a known botanical affinity in that sample. Samples with a higher proportion of multi-affinity sporomorphs offer a less taxonomically precise picture of the source vegetation than samples with a lower proportion of multi-affinity sporomorphs. In this study proportions are reported as percentages and all statistical tests were performed in R (R DCT, 2007).

\section{RESULTS}

\section{Known botanical affinities}

Fifty-six sporomorph taxa were recorded from the 40 productive samples at Astartekløft (Table 3). Of these, exactly 50\% have a known botanical affinity at the family level, 64\% have a known botanical affinity at the order level and $86 \%$ at the class level (Table 3).

There is considerable variation in the proportion of sporomorphs that have a known botanical affinity between individual samples at Astartekløft. Some samples have a smaller proportion of sporomorphs that have a known botanical affinity, and some samples have a larger proportion of sporomorphs that have a known botanical affinity than might be expected based on the total pooled sample set (56 taxa from 40 samples). Within individual samples from Astartekløft, between $48 \%$ and $68 \%$ of sporomorph taxa were produced by a parent plant known at the family level (median 56\%), between $61 \%$ and $84 \%$ of sporomorph taxa were produced by a parent plant known at the order level (median 71\%), and between $79 \%$ and $96 \%$ of sporomorph taxa were produced by a parent plant known at the class level (median 87\%) (Table 3; Fig. 3). A Kruskal-Wallis test indicates that there is a statistically significant difference in the median of each group (family, order and class) ( $\mathrm{KW}=103.1_{40,40,40}$ $p=<0.0001$ ), and this is confirmed by pairwise Mann-Whitney tests (Table 4).

The proportion of sporomorphs that have a known botanical affinity remains fairly constant through time at Astartekløft and no single plant bed stands out as having a markedly lower, or higher, proportion of such sporomorphs (Fig. 4). There is no statistically significant difference in the proportion of sporomorphs with known botanical affinities at the family or order level between plant beds (family: $\mathrm{KW}=12.29_{6,1,4,7,6,9,3,4}$ $p=0.0915$; order: $\left.\mathrm{KW}=9.196_{6}, 1,4,7,6,9,3,4 p=0.2389\right)$. However, plant bed 6 has a higher proportion of sporomorphs with a known botanical affinity at the class level (Fig. 4), and this difference is statistically significant using a Kruskal-Wallis test $\left(\mathrm{KW}=17.72_{6,1,4,7,6,9,3,4} p=0.0133\right)$.

\section{Multiple botanical affinities}

Of those sporomorphs that have a known botanical affinity at Astartekløft, $36 \%$ have affinities to more than one parent plant family, $28 \%$ have affinities to more than one parent plant order, and $23 \%$ have affinities to more than one parent class (Table 3 ).

There is also considerable variation in the proportion of sporomorphs with affinities to more than one parent plant between individual samples at Astartekløft. Some samples have a smaller proportion of multi-affinity sporomorphs and some samples have a larger proportion of multi-affinity sporomorphs than might be expected based on the total pooled sample set. Within individual samples from Astartekløft, between $10 \%$ and $50 \%$ of sporomorphs with a known botanical affinity at the family level have affinities to more than one parent plant family (median 39\%). Between $0 \%$ and $40 \%$ of sporomorphs with a known botanical affinity at the order level have affinities to more than one parent plant order (median 30\%). Between $7.7 \%$ and $39 \%$ of sporomorphs with a known botanical affinity at the class level have affinities to more than one parent plant class (median 


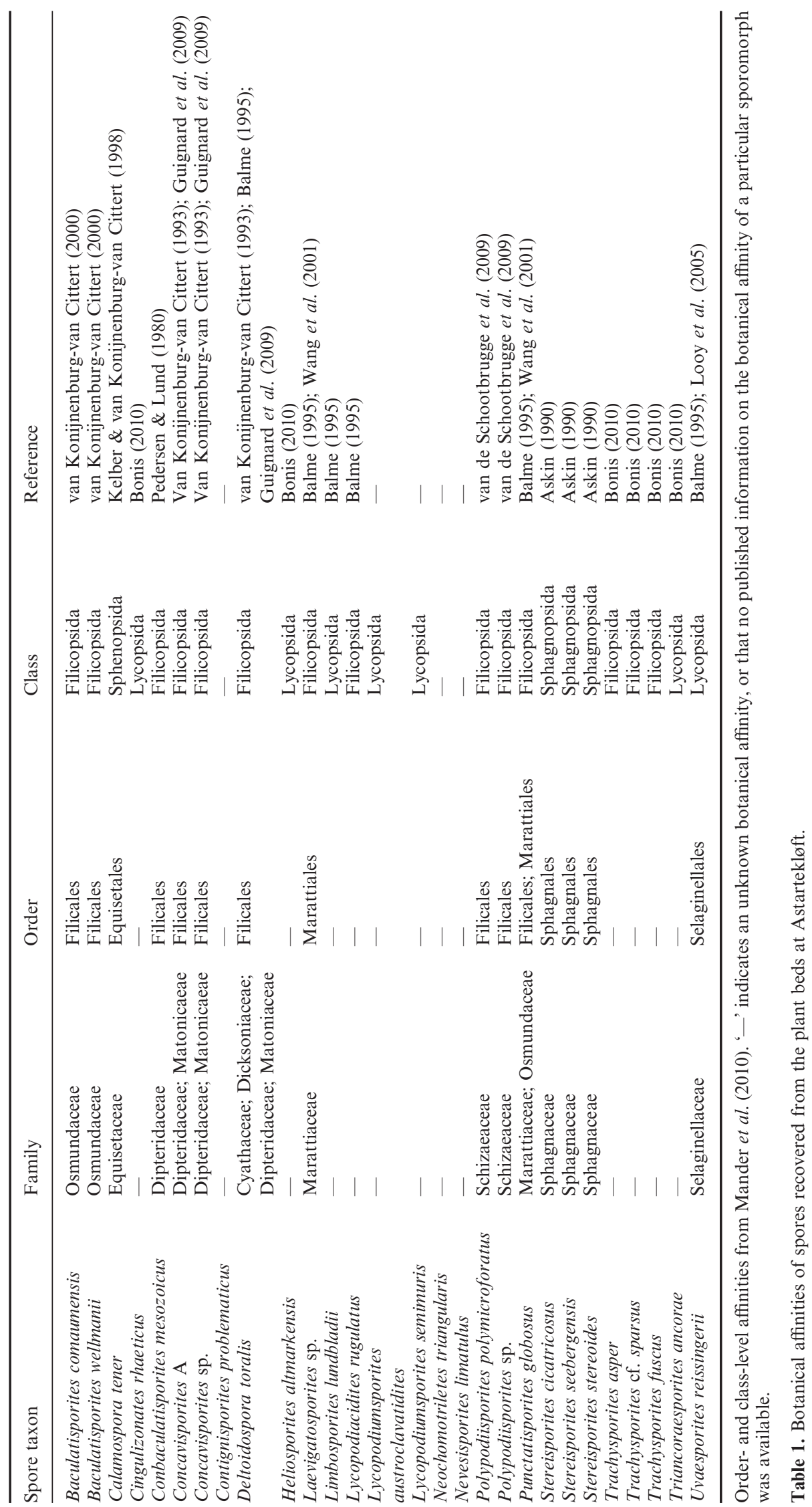


Taxonomic resolution of the sporomorph record in East Greenland

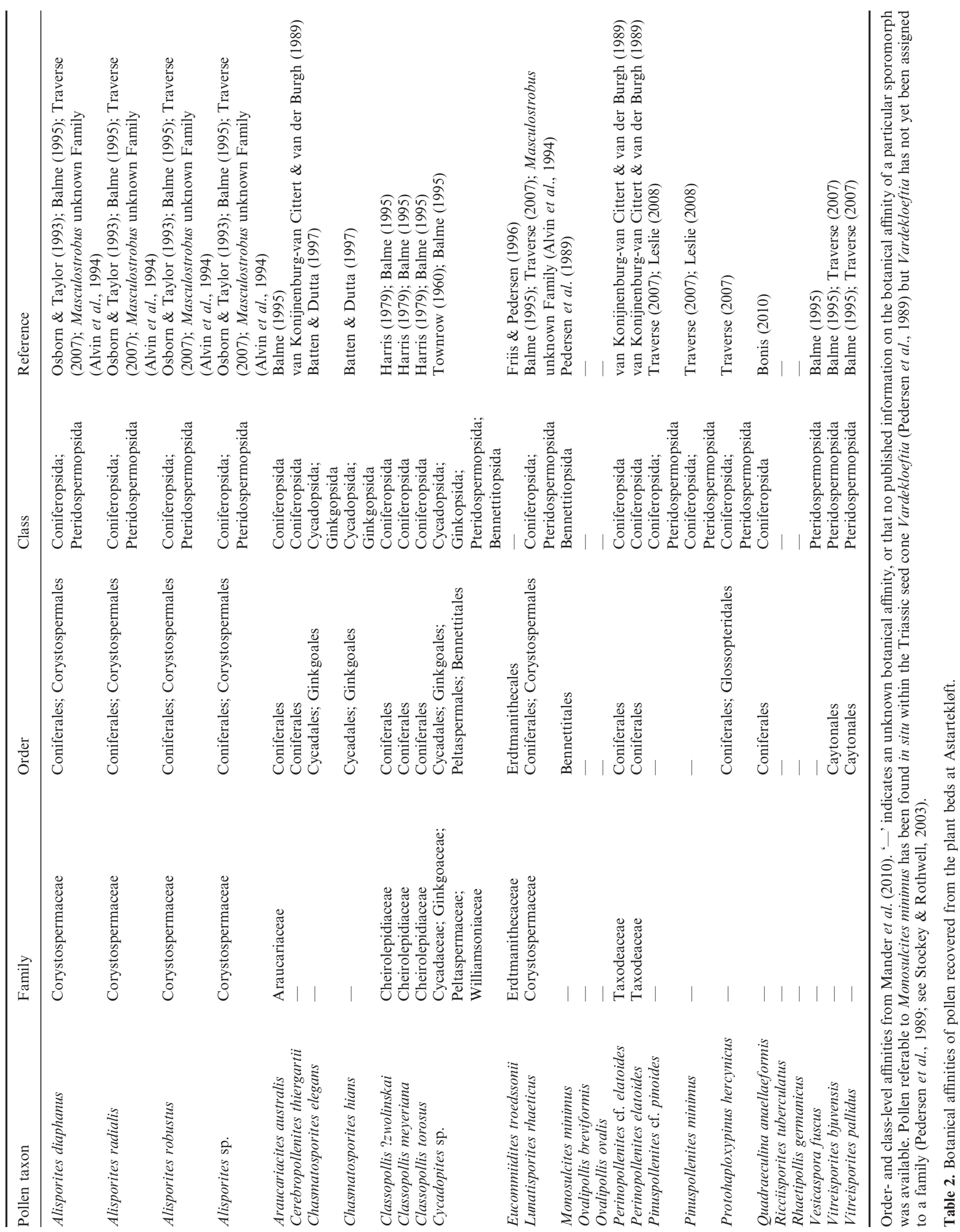









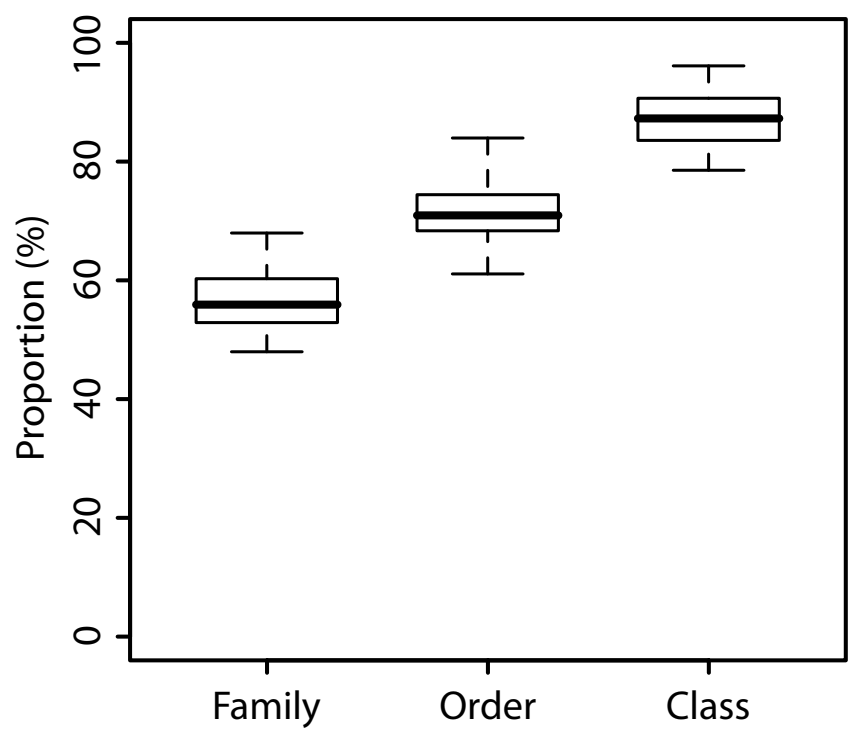

Fig. 3. Box and whisker plot showing the percentage of sporomorphs with a known botanical affinity at the family, order and class levels in individual samples from Astartekløft. Boxes show median and interquartile range, whiskers represent maximum and minimum values.

28\%) (Table 3; Fig. 5). A Kruskal-Wallis test indicates that there is a statistically significant difference in the median of each group (family, order and class) ( $\mathrm{KW}=42.9440,40,40$ $p=<0.0001)$. Pairwise Mann-Whitney tests show that the median proportion of sporomorphs with multiple botanical affinities at the family level is significantly higher than the median proportion of multi-affinity sporomorphs at both the order and class level (Table 4). However, there is no statistically significant difference in the median proportion of multi-affinity sporomorphs between the order and class levels (Table 4).

There is a qualitative increase in the range of percentage values from plant bed 1 to plant bed 5 at Astartekløft, such that the difference between the maximum and minimum proportions of multi-affinity sporomorphs is greatest in plant bed 5 (Fig. 6). Indeed, a single sample from plant bed 5 (labelled 5_4638 in Table 3) has a considerably lower proportion of multi-affinity sporomorphs at all taxonomic levels than other samples (Table 3; Fig. 6). However, there are no statistically significant differences in the median proportion of sporomorphs with multiple botanical affinities between plant beds at Astartekløft (family: $\mathrm{KW}=7.446_{6,1,4,7,6,9,3,4} p=0.384$; order: $\mathrm{KW}=3.165_{6,1,4,7,6,9,3,4} p=0.8693$; class: $\mathrm{KW}=6.690_{6,1,4,7}$, $6,9,3,4 p=0.4618)$.

\section{DISCUSSION}

With how much taxonomic precision do sporomorphs record the source vegetation across the $\mathbf{T r}-\mathbf{J}$ at Astartekløft?

The data presented here provide a clear picture about the taxonomic precision with which sporomorphs record the source vegetation at Astartekløft. Something is known of the botanical affinity of almost all sporomorphs across the $\mathrm{Tr}-\mathrm{J}$ at Astartekløft at the class level (e.g. Table 3; Fig. 3), and this strongly supports the idea that 'at least the broad botanical relationship is known for practically all Mesophytic sporomorphs' (Traverse, 2007, p. 312). However, just 50\% of sporomorph taxa at Astartekløft have a known botanical affinity at the family level (e.g. Table 3), and this highlights that reconstructions of $\mathrm{Tr}-\mathrm{J}$ vegetation based on sporomorphs at Astartekløft (e.g. Pedersen \& Lund, 1980) are hampered by considerable taxonomic imprecision because the parent plants of many sporomorphs are unknown at the family level.

Additionally, although something is known of the botanical affinity of most sporomorphs at Astartekløft (e.g. Fig. 3), a considerable number of these sporomorphs have affinities to more than one parent plant. For example, $\sim 23 \%$ of all sporomorph taxa at Astartekløft have affinities to more than one parent plant class, and $\sim 36 \%$ of all sporomorph taxa at Astartekløft have affinities to more than one parent plant family (e.g. Table 3), and this compounds the taxonomic imprecision of sporomorph assemblages at Astartekløft. Three groups of sporomorphs stand out as 'problem taxa' that are morphologically invariant among certain parent plant classes, orders and/or families: smooth trilete spores, smooth or scabrate 'boat-shaped' monosulcate pollen grains, and bisaccate pollen grains. Among smooth trilete spores, Deltoidospora toralis has affinities to four parent families and Concavisporites spp. has affinities to two parent plant families (Table 1). Among biscaccate pollen grains, Alisporites, Pinuspollenites, Lunatisporites and Protohaploxypinus have affinities to two parent classes and orders (Table 2). Among 'boat-shaped' monosulcate pollen grains, Cycadopites has affinities to four parent classes, orders and families, while Chasmatosporites has affinities to two classes and orders (Table 2).

Several authors have commented on these 'problem taxa'. Balme (1995) noted that smooth or scabrate 'boat-shaped' monosulcate pollen grains are almost identical when viewed under light microscopy despite being produced by several plant orders (e.g. Frederiksen, 1980) and Mesozoic bisaccate pollen is similarly difficult to cope with systematically (e.g. Traverse, 2007). The bisaccate morphogenus Alisporites has strong affinities to both conifers and corystosperms (a clade of

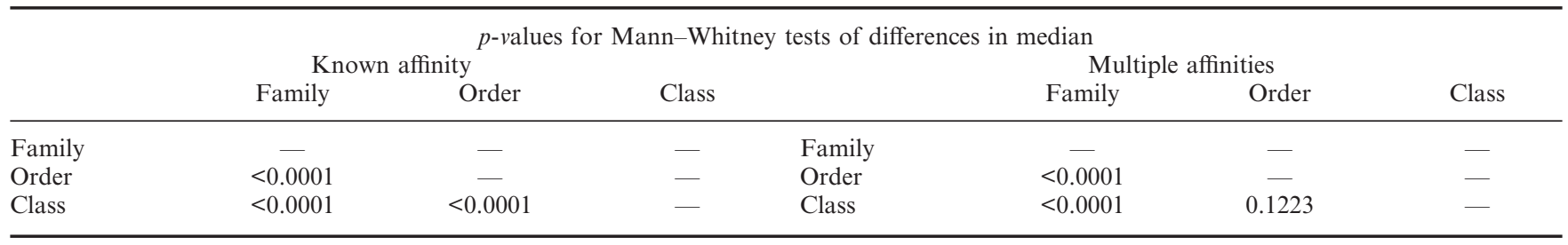

Table 4. Pairwise Mann-Whitney significance tests of differences in the median proportion of sporomorphs with known botanical affinities and multiple botanical affinities, at the family order and class level at Astartekløft. 

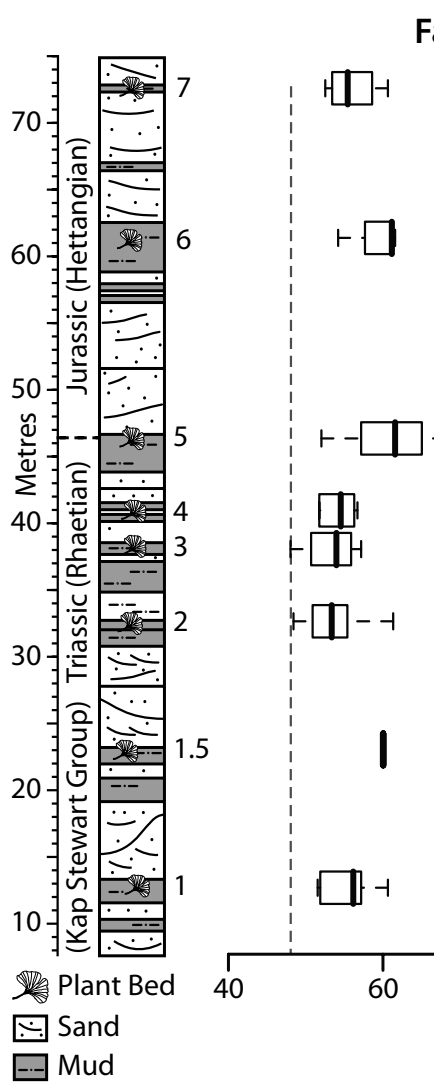

Family

Fig. 4. Box and whisker plots showing the percentage of sporomorphs with a known botanical affinity at the family, order and class levels within each plant bed at Astartekløft. Boxes show median and interquartile range, whiskers represent maximum and minimum values. Vertical grey dashed lines represent minimum and maximum percentages recorded in the entire section, which correspond to the maximum and minimum percentages shown in Figure 3 (see also Table 3). seed-ferns) (Table 2) and is a classic case of morphological invariance of a sporomorph at a high taxonomic level.

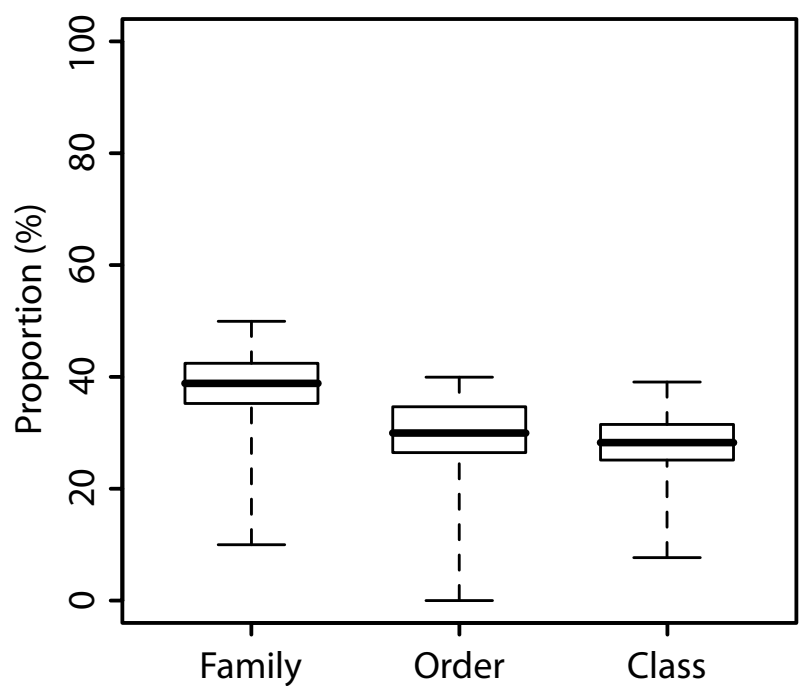

Fig. 5. Box and whisker plot showing the percentage of sporomorphs with multiple botanical affinities at the family, order and class levels in individual samples from Astartekløft. Boxes show median and interquartile range, whiskers represent maximum and minimum values.
Traverse (2007, p. 317) commented, 'It seems likely that the conifer and corystosperm bisaccate pollen referred to this morphogenus will eventually be separated', but splitting sporomorphs into biologically meaningful morphotypes is not straightforward. Scanning electron microscopy (SEM) can be used to separate different sporomorph morphotypes but characters visible under SEM, such as very fine surface sculpture, are not always visible under light microscopy (e.g. Liu et al., 2007) because the diffraction limit of light limits the resolution of most high numerical aperture objectives to $250-300 \mathrm{~nm}$ (Weiss, 2000). Just as one sporomorph morphotype can have affinities to more than one parent plant, one plant can produce a number of different sporomorph morphotypes. For example, Lindström et al. (1997) demonstrated that Late Permian glossopterid sporangia contained saccate pollen grains referable to at least two separate bisaccate morphogenera (Protohaploxypinus and Striatopodocarpidites), together with sporadic monosaccate and trisaccate grains that could be assigned to several other morphotaxa. Such intraspecific and/or ontogenetic variation in sporomorph morphology highlights that separation of dispersed sporomorphs into as many morphotypes as possible is not an appropriate way to improve the taxonomic resolution of the sporomorph record, and reinvestigation of in situ material, together with focused ultrastructural studies, is essential. 


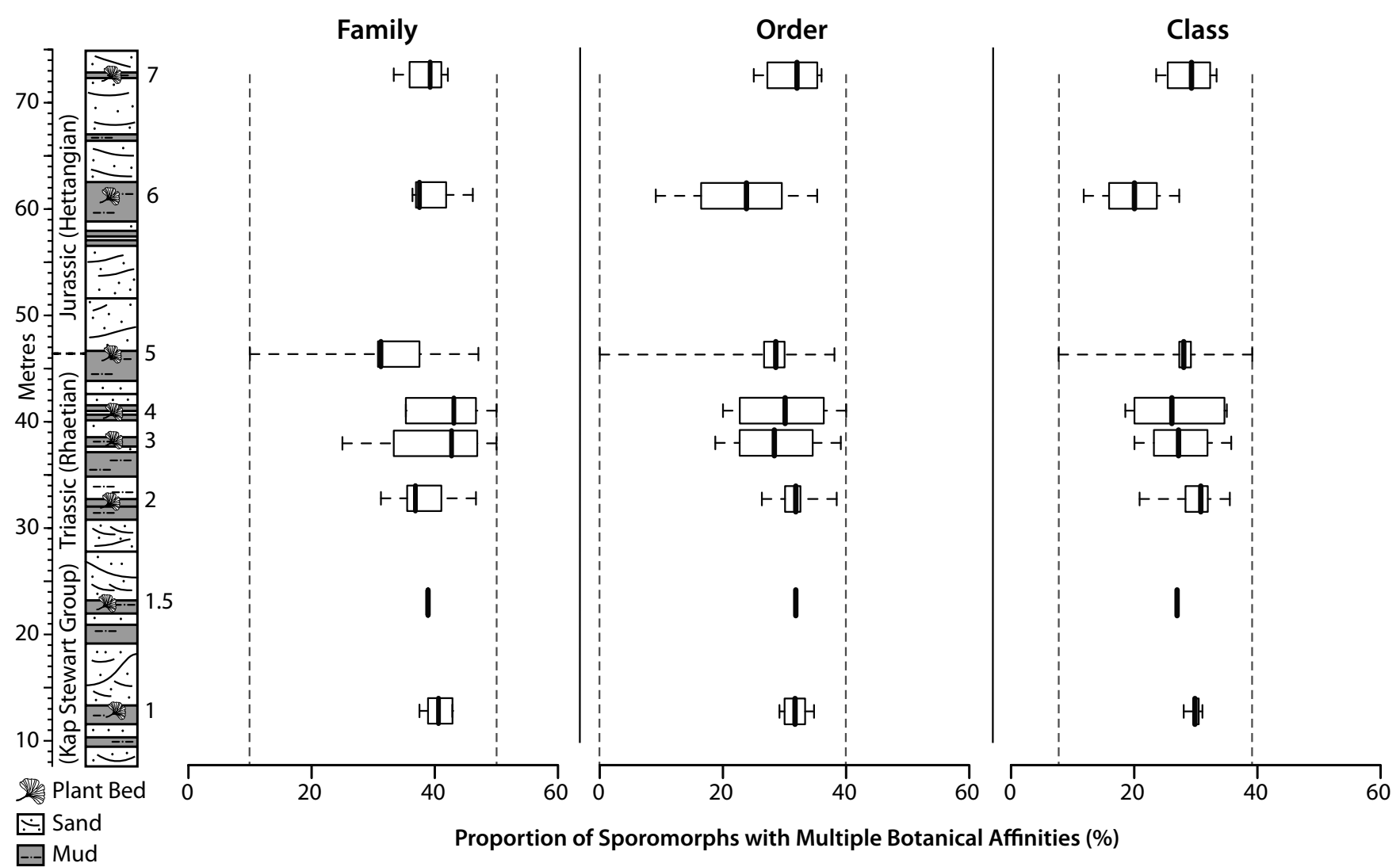

Fig. 6. Box and whisker plots showing the percentage of sporomorphs with multiple botanical affinities at the family, order and class levels within each plant bed at Astartekløft. Boxes show median and interquartile range, whiskers represent maximum and minimum values. Vertical grey dashed lines represent minimum and maximum percentages recorded in the entire section, which correspond to the maximum and minimum percentages shown in Figure 5 (see also Table 3).

\section{Vegetation composition and diversity at Astartekløft}

The taxonomic resolution of the sporomorph record at Astartekløft does not change appreciably through time (Figs 4, 6). This implies that reconstructions of vegetation based on sporomorphs will be taxonomically smoothed to a very similar degree in the eight plant beds and three different depositional environments at Astartekløft that have been analysed here (see Fig. 2). It has been shown previously that there is a significant and likely permanent change in the composition of sporomorph assemblages across the $\operatorname{Tr}-\mathbf{J}$ at Astartekløft (Mander et al., 2010). This compositional change begins in the topmost upper Rhaetian (plant bed 5; see Fig. 2) and is sustained into the Hettangian (plant beds 6 and 7; see Fig. 2) (Mander et al., 2010). Given that the proportion of sporomorphs with a known botanical affinity at the class level is highest in plant bed 6 and that certain samples in plant bed 5 contain the lowest proportion of multiaffinity sporomorphs (Figs 4, 6), this compositional change did not result in a loss of taxonomic precision among $\mathrm{Tr}-\mathrm{J}$ sporomorph assemblages at Astartekløft.

The results presented here also strongly support the idea that sporomorphs underestimate the number of plant taxa in the source vegetation at Astartekløft (Mander et al., 2010). For example, the pollen grain Cycadopites was produced by at least four different plant families at the $\operatorname{Tr}-\mathbf{J}$ (Table 2). Under the assumption that each of these families is monospecific, then this taxon masks at least three additional species. By repeating this for each sporomorph taxon at Astartekløft (see Tables 1, 2), the total number of sporomorph taxa rises from 56 to 75 . This suggests that sporomorphs underestimate the diversity of the source vegetation at Astartekløft by at least $\sim 25 \%$. Such underestimation of diversity is expected based on comparisons of floristic and sporomorph diversity in the modern world. For example, as reviewed by Odgaard (1999), 2990 species were reported in the flora of vascular plants in the British Isles by Stace (1991), but just 390 sporomorph taxa were included in the list of pollen and spore types of vascular plants in the British Isles by Bennett (1996). Changes in sporomorph diversity across the $\mathrm{Tr}-\mathrm{J}$ in East Greenland (Mander et al., 2010) and in central Europe (e.g. Bonis et al., 2009) are, therefore, likely to underestimate the magnitude of diversity changes in the source vegetation, as has been suggested for the sporomorph record of vegetation change during the Paleocene-Eocene Thermal Maximum in North America (Harrington \& Jaramillo, 2007).

\section{Taxonomic imprecision of $\mathbf{T r}-\mathbf{J}$ sporomorph assemblages at} Astartekløft: macrofossils and implications

Macrofossil assemblages at Astartekløft contain a high proportion of woody plants, such as cycads, bennettites, ginkgos and conifers, whereas sporomorph assemblages contain a high proportion of spore-producing plants, such as ferns (Table 5; Mander et al., 2010). This highlights that macrofossils and sporomorphs provide different and complementary pictures of 


\begin{tabular}{llr}
\hline Plant group & Macrofossils vs. sporomorphs & Mean difference (\%) \\
\hline Ferns & Generally a greater component of sporomorph record & -22 \\
Conifers and corystosperms & Far greater component of macrofossil record where & 12 \\
Monosulcate producers & Podozamites and Stachyotaxus dominate & 49 \\
\hline
\end{tabular}

The plant group 'Monosulcate producers' comprises cycads, bennettites, ginkgos and the seed-fern Lepidopteris. 'Mean difference' refers to the average discrepancy between the macrofossil and sporomorph records of each plant group at Astartekløft (from Mander et al., 2010).

Table 5. Comparison of macrofossil and sporomorph records of the source vegetation at Astartekløft.

the source vegetation at Astartekløft. Certain aspects of $\mathrm{Tr}-\mathrm{J}$ vegetation change at Astartekløft are not recorded in the sporomorph record but are clearly expressed in the macrofossil record. For example, the extinction of the Peltaspermaceae at the $\operatorname{Tr}-\mathrm{J}$ boundary is clear in the macrofossil record and is marked by the disappearance of the leaf genus Lepidopteris (e.g. McElwain et al., 2007), but this extinction is masked in the sporomorph record because of the morphological invariance of the pollen grain Cycadopites among the Cycadales, Ginkgoales, Bennettitales and Peltaspermales (Table 2; Mander et al., 2010). This provides support for the view that macrofossils can offer a more taxonomically precise view of the source vegetation than sporomorphs (e.g. Jackson \& Booth, 2007), and highlights that in certain situations macrofossils can be usefully incorporated into studies of $\mathrm{Tr}-\mathbf{J}$ vegetation change.

There are other cases, however, that urge caution in the use of macrofossils to study vegetation change across the $\operatorname{Tr}-\mathbf{J}$. For example, 10 species of Pterophyllum have been reported from the Jameson Land region in East Greenland (Harris, 1937), but a recent comprehensive macromorphological and cuticular study of bennettitaleans from Sweden has reduced the number of mid-Mesozoic bennettite species within Pterophyllum to just five (Pott \& McLoughlin, 2009). Such taxonomic over-splitting means that the $\sim 85 \%$ decline in standing species richness in the Jameson Land region at the $\operatorname{Tr}-\mathrm{J}$ (Harris, 1937; McElwain et al., 2007 ) is probably too high and full taxonomic revision of the macrofossils in this region is necessary. This highlights that for some groups it is unclear to what extent current fossil leaf taxonomy reflects true plant diversity in the source vegetation. Palaeoecological studies undertaken at the generic level (e.g. McElwain et al., 2007, 2009) are more robust to such problems because they are more taxonomically conservative.

Sporomorphs provide an excellent record of ancient vegetation because they have high fossilization potential, are widely dispersed and thus representative of regional vegetation (e.g. Farley, 1990), and can be sampled at very high stratigraphic resolution. This study has provided an example of one key limitation of sporomorphs: they record the source vegetation at low taxonomic resolution (e.g. Figs 4, 6). There are some situations in which such taxonomic imprecision may be less problematic, such as in large-scale analyses of sporomorph diversity over long time periods where the number of morphospecies (rather than their systematic affinity) is the primary consideration (e.g. Jaramillo et al., 2006). There are other situations, however, where such taxonomic imprecision is wholly undesirable. For example, when interpreting diagrams of the percentages of sporomorph taxa across the $\operatorname{Tr}-\mathrm{J}$ (e.g. Pedersen \& Lund, 1980; Kuerschner et al., 2007; Bonis et al., 2009; van de
Schootbrugge et al., 2009), it should be borne in mind that smooth trilete spores (such as Deltoidospora), smooth or scabrate 'boat-shaped' monosulcate pollen grains (such as $\mathrm{Cyca}$ dopites) and bisaccate pollen grains (such as Alisporites) are 'problem taxa' that have affinities to several parent plant groups (e.g. Tables 1, 2).

\section{CONCLUDING REMARKS}

1. Reconstructions of $\operatorname{Tr}-\mathbf{J}$ vegetation based on sporomorphs at Astartekløft (e.g. Pedersen \& Lund, 1980) are hampered by considerable taxonomic imprecision. Something is known of the botanical affinity of almost all sporomorphs at Astartekløft at the class level (e.g. Table 3; Fig. 3), but just $50 \%$ of sporomorph taxa at Astartekløft have a known botanical affinity at the family level (e.g. Table 3). Additionally, $\sim 23 \%$ of all sporomorph taxa at Astartekløft have affinities to more than one parent plant class, and $\sim 36 \%$ of all sporomorph taxa at Astartekløft have affinities to more than one parent plant family (e.g. Table 3). This taxonomic imprecision should be taken into account when interpreting diagrams of the percentages of sporomorph taxa across the $\operatorname{Tr}-\mathbf{J}$ in East Greenland (e.g. Pedersen \& Lund, 1980) and elsewhere in Europe (e.g. Kuerschner et al., 2007; Bonis et al., 2009; van de Schootbrugge et al., 2009).

2. The taxonomic resolution of the sporomorph record remains fairly constant across the $\operatorname{Tr}-\mathbf{J}$ at Astartekløft. No single plant bed or depositional environment stands out as having a markedly lower or higher proportion of sporomorphs with a known botanical affinity (Fig. 4), or a markedly lower or higher proportion of sporomorphs with affinities to more than one parent plant (Fig. 6).

3. Three groups of sporomorphs stand out as 'problem taxa' that are morphologically invariant among certain parent plant classes, orders and/or families. These are: (a) the smooth trilete spores Deltoidospora toralis (four parent families) and Concavisporites spp. (two parent plant families) (Table 1); (b) the biscaccate pollen grains Alisporites, Pinuspollenites, Lunatisporites and Protohaploxypinus (two parent classes and orders) (Table 2); (c) the 'boat-shaped' monosulcate pollen grains Cycadopites (four parent classes, orders and families) and Chasmatosporites (two parent classes and orders) (Table 2). Detailed investigation of reproductive structures to find sporomorphs in situ, reinvestigation of existing in situ material, and ultrastructural studies of problematic sporomorphs should improve the taxonomic resolution of the $\mathrm{Tr}-\mathrm{J}$ sporomorph record. 
4. Sporomorphs probably underestimate the diversity of the source vegetation at Astartekløft by at least $\sim 25 \%$, and changes in sporomorph diversity across the $\mathrm{Tr}-\mathrm{J}$ (e.g. Bonis et al., 2009; Mander et al., 2010) are likely to underestimate the magnitude of diversity changes in the source vegetation. If data from the plant fossil record are to be brought to bear on issues such as the present-day climate and biodiversity crises (e.g. McElwain \& Punyasena, 2007), it is essential that the relationship between dispersed sporomorph diversity and the diversity of plants in the source vegetation is well understood.

\section{ACKNOWLEGEMENTS}

I thank Guy Harrington and Charles Wellman for constructive reviews and Claire Belcher for critical comments on an earlier draft of this work. I gratefully acknowledge discussions with Jennifer McElwain and Wolfram Kürschner, and funding through a Marie Curie Early Stage Research Fellowship (Marie Curie Excellence Grant: MEXT-CT-2006-042531).

\section{Manuscript received 10 January 2011 \\ Manuscript accepted 14 May 2011}

Scientific editing by Tom Dunkley Jones

\section{REFERENCES}

Alvin, K.L., Watson, J. \& Spicer, R.A. 1994. A new coniferous male cone from the English Wealden and a discussion of pollination in the Cheirolepidiaecae. Palaeontology, 37: 173-180.

Askin, R.A. 1990. Cryptogam spores from the upper Campanian and Maastrichtian of Seymour Island, Antarctica. Micropalaeontology, 36: 141-156.

Balme, B.E. 1995. Fossil in situ spores and pollen grains: an annotated catalogue. Review of Palaeobotany and Palynology, 87: 81-323.

Batten, D.J. \& Dutta, R.J. 1997. Ultrastructure of exine of gymnospermous pollen grains from Jurassic and basal Cretaceous deposits in Northwest Europe and implications for botanical relationships. Review of Palaeobotany and Palynology, 99: 25-54.

Belcher, C.M., Mander, L., Rein, G. et al. 2010. Increased fire activity at the Triassic/Jurassic boundary in Greenland due to climate-driven floral change. Nature Geoscience, 3: 426-429.

Bennett, K.D. 1996. Catalogue of Pollen Types. Available online at: http://chrono.qub.ac.uk/pollen/pc-intro.html.

Benton, M.J. 1995. Diversification and extinction in the history of life. Science, 268: 52-58.

Birks, H.H. \& Birks, H.J.B. 2000. Future uses of pollen analysis must include plant macrofossils. Journal of Biogeography, 27: 31-35.

Bonis, N.R. 2010. Palaeoenvironmental changes and vegetation history during the Triassic-Jurassic transition. LPP Contribution Series, 29, 216pp.

Bonis, N.R., Kürschner, W.M. \& Krystyn, L. 2009. A detailed palynological study of the Triassic-Jurassic transition in key sections of the Eiberg Basin (Northern Calcareous Alps, Austria). Review of Palaeobotany and Palynology, 156: 376-400.

Dam, G. \& Surlyk, F. 1992. Forced regressions in a large waveand storm-dominated anoxic lake, Kap Stewart Formation, East Greenland. Geology, 20: 749-752.

Dam, G. \& Surlyk, F. 1993. Cyclic sedimentation in a large wave- and storm-dominated anoxic lake; Kap Stewart Formation (RhaetianSinemurian) Jameson Land, East Greenland. In: Posamentier, H.W., Summerhayes, C.P., Haq, B.U. \& Allen, G.P. (Eds), Sequence Stratigraphy and Facies Associations. International Association of Sedimentologists, Special Publication, 18: 419-438.
Domínguez-Vázquez, G.A., Islebe, G.A. \& Villanueva-Gutiérrez, R. 2004. Modern pollen deposition in Lacandon forest, Chiapas, Mexico. Review of Palaeobotany and Palynology, 131: 105-116.

Farley, M.B. 1990. Vegetation distribution across the early Eocene depositional landscape from palynological analysis. Palaeogeography, Palaeoclimatology, Palaeoecology, 79: 11-27.

Frederiksen, N.O. 1980. Significance of monosulcate pollen abundance in Mesozoic sediments. Lethaia, 13: 1-20.

Friis, E.M. \& Pedersen, K.R. 1996. Eucommiitheca hirsuta, a new pollen organ with Eucommiidites pollen from the Early Cretaceous of Portugal. Grana, 35: 104-112.

Guignard, G., Wang, Y., Ni, Q., Tian, N. \& Jiang, Z. 2009. A dipteridaceous fern with in situ spores from the Lower Jurassic in Hubei, China. Review of Palaeobotany and Palynology, 156: $104-115$.

Harrington, G.J. \& Jaramillo, C.A. 2007. Paratropical floral extinction in the Late Paleocene-Early Eocene. Journal of the Geological Society, London, 164: 323-332.

Harris, T.M. 1937. The fossil flora of Scoresby Sound East Greenland, Part 5. Stratigraphic relations of the plant beds. Meddelelser om Gronland, 112(2): 1-112.

Harris, T.M. 1979. The Yorkshire Jurassic Flora V. Coniferales. British Museum, Natural History, London.

Hesselbo, S.P., Robinson, S.A., Surlyk, F. \& Piasecki, S. 2002. Terrestrial and marine extinction at the Triassic-Jurassic boundary synchronized with major carbon cycle perturbation: a link to initiation of massive volcanism? Geology, 30: 251-254.

Jackson, S.T. \& Booth, R.T. 2007. Validation of pollen studies. In: Elias, S.A. (Ed.), Encyclopaedia of Quaternary Sciences. Elsevier Scientific Publishing, Amsterdam, 2413-2422.

Jaramillo, C., Rueda, M.J. \& Mora, G. 2006. Cenozoic plant diversity in the Neotropics. Science, 311: 1893-1896.

Kelber, K.-P. \& van Konijnenburg-van Cittert, J.H.A. 1998. Equisetites arenaceus from the Upper Triassic of Germany with evidence for reproductive strategies. Review of Palaeobotany and Palynology, 100: $1-26$.

Koppelhus, E.B. 1996. Palynology of the lacustrine Kap Stewart Formation, Jameson Land, East Greenland. Danmark og Grønlands Geologiske Undersogelse Rapport, Appendix 5, 1-30.

Kuerschner, W.M., Bonis, N.R. \& Krystyn, L. 2007. Carbon-isotope stratigraphy and palynostratigraphy of the Triassic-Jurassic transition in the Tiefengraben section - Northern Calcareous Alps (Austria). Palaeogeography, Palaeoclimatology, Palaeoecology, 244: 257-280.

Leslie, A.B. 2008. Interpreting the function of saccate pollen in ancient conifers and other seed plants. International Journal of Plant Sciences, 169: $1038-1045$.

Lindström, S., McLoughlin, A. \& Drinnan, A.N. 1997. Intraspecific variation of taeniate bisaccate pollen within Permian glossopterid sporangia, from the Prince Charles Mountains, Antarctica. International Journal of Plant Sciences, 158: 673-684.

Liu, Y-S., Zetter, R., Ferguson, D.K. \& Mohr, B.A.R. 2007. Discriminating fossil evergreen and deciduous Quercus pollen: A case study from the Miocene of eastern China. Review of Palaeobotany and Palynology, 145: 289-303.

Looy, C.V., Collinson, M.E., van Konijnenburg-van Cittert, J.H.A., Visscher, H. \& Brain, A.P.R. 2005. The ultrastructure and botanical affinity of end-Permian spore tetrads. International Journal of Plant Sciences, 166: 875-887.

Lund, J.J. 1977. Rhaetic to Lower Liassic palynology of the onshore south-eastern North Sea Basin. Geological Survey of Denmark, 109: $1-129$.

Mander, L., Kürschner, W.M. \& McElwain, J.C. 2010. An explanation for conflicting records of Triassic-Jurassic plant diversity. Proceedings of the National Academy of Sciences, USA, 107: 15 351-15 356.

McElwain, J.C., Popa, M.E., Hesselbo, S.P., Haworth, M. \& Surlyk, F. 2007. Macroecological responses of terrestrial vegetation to climatic and atmospheric change across the Triassic/Jurassic boundary in East Greenland. Paleobiology, 33: 547-573.

McElwain, J.C. \& Punyasena, S.W. 2007. Mass extinction events and the plant fossil record. Trends in Ecology and Evolution, 22: 548-557. 
McElwain, J.C., Wagner, P.J. \& Hesselbo, S.P. 2009. Fossil plant relative abundances indicate sudden loss of Late Triassic biodiversity in East Greenland. Science, 324: 1554-1556.

Mitchell, F.J.G. 2011. Exploring vegetation in the fourth dimension. Trends in Ecology and Evolution, 26: 45-52.

Morbey, S.J. 1975. The palynostratigraphy of the Rhaetian stage, Upper Triassic in the Kendelbachgraben, Austria. Palaeontographica B, 152: $1-75$.

Odgaard, B.V. 1999. Fossil pollen as a record of past biodiversity. Journal of Biogeography, 26: 7-17.

Osborn, J.M. \& Taylor, T.N. 1993. Pollen morphology and ultrastructure of the Corystospermales: permineralized in situ grains from the Triassic of Antarctica. Review of Palaeobotany and Palynology, 79: 205-219.

Overpeck, J.T., Webb, R.S. \& Webb, T. III 1992. Mapping eastern North American vegetation change of the past $18 \mathrm{ka}$ : No-analogs and the future. Geology, 20: 1071-1074.

Pedersen, K.R., Crane, P.R. \& Friis, E.M. 1989. The morphology and phylogenetic significance of Vardekloeftia Harris (Bennettitales). Review of Palaeobotany and Palynology, 60: 7-24.

Pedersen, K.R. \& Lund, J.J. 1980. Palynology of the plant-bearing Rhaetian to Hettangian Kap Stewart Formation, Scoresby Sund, East Greenland. Review of Palaeobotany and Palynology, 31: 1-69.

Pott, C. \& McLoughlin, S. 2009. Bennettitalean foliage in the RhaetianBajocian (latest Triassic-Middle Jurassic) floras of Scania, southern Sweden. Review of Palaeobotany and Palynology, 158: 117-166.

R DCT. 2007. R: A language and environment for statistical computing. R Foundation for Statistical Computing, Vienna, Austria.

Schoene, B., Guex, J., Bartolini, A., Schaltegger, U. \& Blackburn, T.J. 2010. Correlating then end-Triassic mass extinction and flood basalt volcanism at the $100 \mathrm{ka}$ level. Geology, 38: 387-390.

Schuster, R.M. 1992. The Hepataceae and Anthocerotae of North America, Volume 6. Field Museum of Natural History, Chicago, 506pp.

Stace, C. 1991. New Flora of the British Isles. Cambridge University Press, Cambridge.

Stockey, R.A. \& Rothwell, G.W. 2003. Anatomically preserved Williamsonia (Williamsoniaceae): evidence for bennettitalean reproduction in the Late Cretaceous of western North America. International Journal of Plant Sciences, 164: 251-262.

Surlyk, F. 2003. The Jurassic of East Greenland: a sedimentary record of thermal subsidence, onset and culmination of rifting. In: Ineson,
J.R. \& Surlyk, F. (Eds), The Jurassic of Denmark and Greenland. Geological Survey of Denmark and Greenland, Copenhagen, 659-723.

Townrow, J.A. 1960. The Peltaspermaceae, a pteridosperm family of Permian and Triassic age. Palaeontology, 3: 333-361.

Traverse, A. 2007. Paleopalynology (2nd edn.). Springer, The Netherlands, 813pp.

van de Schootbrugge, B., Quan, T.M., Lindström, S. et al.. 2009. Floral changes across the Triassic/Jurassic boundary linked to flood basalt volcanism. Nature Geoscience, 2: 589-594.

van Konijnenburg-van Cittert, J.H.A. 1993. A review of the Matoniaceae based on in situ spores. Review of Palaeobotany and Palynology, 78: 235-267.

van Konijnenburg-van Cittert, J.H.A. 2000. Osmundaceous spores throughout time. In: Harley, M.M., Morton, C.M. \& Blackmore, S. (Eds), Pollen and Spores: Morphology and Biology. Royal Botanic Gardens, Kew, 435-449.

van Konijnenburg-van Cittert, J.H.A. \& van der Burgh, J. 1989. The flora from the Kimmeridgian (Upper Jurassic) of Culgower, Sutherland, Scotland. Review of Palaeobotany and Palynology, 61: $1-51$.

Villarreal, J.C., Hässel de Menéndx, G. \& Allen, N.R. 2007. Nothoceras superbus (Dendrocerotaceae), a new hornwort from Costa Rica. The Bryologist, 110: 279-285.

von Post, L. 1916. Om skogsträdpollen i sydsvenska torfmosselagerföljder (foredragsreferat). Geolgiska Föereningen i Stockholm. Föerhandlingar, 38: 384-390. (Translated by Davis, M.B. \& Fægri, K. 1967. Forest tree pollen in Swedish peat bog deposits. Pollen et Spores, 9: 378-401. Reprinted in Real, L.A. \& Brown, J.H. 1991. Foundations of Ecology. The University of Chicago Press, Chicago \& London, 456-482.)

Wang, Y., Guignard, G., Lugardon, B. \& Barale, G. 2001. Ultrastructure of in situ Marattia asiatica (Marattiaceae) spores from the Lower Jurassic in Hubei, China. International Journal of Plant Sciences, 162: 927-963.

Weiss, S. 2000. Shattering the diffraction limit of light: A revolution in fluorescence microscopy? Proceedings of the National Academy of Sciences, USA, 97: 8747-8749.

Wodehouse, R.P. 1935. Pollen Grains. McGraw-Hill, New York, $574 \mathrm{pp}$. 